\title{
The Association of Tobacco mosaic virus with Green Spot of Cured Wrapper Tobacco Leaves
}

\author{
J. A. LaMondia, The Connecticut Agricultural Experiment Station, Valley Laboratory, Windsor 06095
}

\begin{abstract}
LaMondia, J. A. 2008. The association of Tobacco mosaic virus with green spot of cured wrapper tobacco leaves. Plant Dis. 92:37-41.

Near-isogenic lines of cigar wrapper tobacco resistant or susceptible to Tobacco mosaic virus (TMV) were used to evaluate the association of TMV infection with green spot symptoms in cured leaves. TMV infection, as determined by double-antibody sandwich enzyme-linked immunosorbent assay (ELISA), was detected on susceptible but not resistant plants in field experiments. Green spot severity on cured leaves was greater for susceptible than resistant plants, even when symptoms of TMV were not evident in the field. Some green spots were present on resistant leaves despite the fact that the virus was not detected by ELISA. Resistant and susceptible plants had similar responses to virus infection and similar ELISA detection of TMV when plants were held at continuous temperatures over $28^{\circ} \mathrm{C}$ in growth chambers. Plant resistance was not compromised in the field in cloth-covered shade tents even when 33.5 of the $96 \mathrm{~h}$ immediately following inoculation were above $28^{\circ} \mathrm{C}$. Green spot of cured leaves was strongly associated with TMV infection in susceptible plants, even when plants were infected after leaf expansion and mosaic symptoms were not present. Green spot also occurred to a lesser extent and for a limited time in inoculated resistant plants. The development of green spot symptoms on cured leaves may be the result of either systemic infection of TMV-susceptible plants or associated with the systemic resistance response to TMV inoculation of resistant plants.
\end{abstract}

Additional keyword: $N$-gene

Tobacco mosaic virus (TMV) has long been a common and important pathogen of cigar wrapper tobacco types in the Connecticut River Valley of Connecticut and Massachusetts. The disease recently has been successfully managed by the incorporation of genetic resistance derived from Nicotiana glutinosa into the most widely grown shade and broadleaf tobacco cultivars. This resistance is conferred by a single dominant gene ( $N$ locus) that results in a hypersensitive local lesion reaction (5).

Connecticut and Massachusetts cigar tobacco growers often produce their own seed, often without selection for TMV resistance, and genetic drift can result in the loss of resistance. TMV-resistant tobacco may be less vigorous than similar susceptible lines (5); therefore, maintaining resistance in tobacco populations may be problematic, especially if the largest and most vigorous plants are selected.

Symptoms of early TMV infection of susceptible cultivars range from the mottled dark and light green typical of this disease to a leaf burn, strapped leaves, and plant stunting. Because cigar wrapper to-

Corresponding author: J. A. LaMondia

E-mail: James.LaMondia@po.state.ct.us

Accepted for publication 22 August 2007.

doi:10.1094/PDIS-92-1-0037

(C) 2008 The American Phytopathological Society bacco leaves need to be of uniform color and blemish-free to be marketable, symptomatic leaves (shade-grown) or plants (broadleaf) are not harvested. Late-season secondary infection within the crop often does not result in visible symptoms on green leaves; however, we have noticed an increased incidence of green spots (Fig. 1) present on the leaves after curing $(6 ; \mathrm{J}$. A. LaMondia, unpublished).

Recent TMV epidemics in flue-cured and other tobacco types have resulted in increased incidence of inoculum present in many tobacco products (9). The combination of widespread TMV inoculum and an inadvertent loss of TMV resistance in two of the most widely grown wrapper-tobacco cultivars in the Connecticut River Valley mentioned above resulted in severe losses due to TMV symptoms on tobacco in the field and green spot on cured leaves in 2004 and 2005. TMV resistance is temperature dependent and has been reported to fail at temperatures above $28^{\circ} \mathrm{C}$ (1). Although temperatures in shade tents in Connecticut often exceed $28^{\circ} \mathrm{C}$ during hot summer weather, the impact of these temperatures on TMV infection of these plants has not been determined.

The objectives of this research were to determine (i) whether TMV was associated with green spot on cured leaves of nonsymptomatic wrapper tobacco, (ii) the effects of plant resistance on green spot incidence and severity, and (iii) the effects of temperature and inoculation timing and technique on the development of TMV on resistant or susceptible tobacco plants in the field and green spot on cured leaves.

\section{MATERIALS AND METHODS}

Virus source and host plants. The common strain of TMV maintained at the Connecticut Agricultural Experiment Station Valley Laboratory for evaluation of tobacco resistance in breeding programs was used in these experiments. The TMV was increased and maintained on TMVsusceptible tobacco lines and tested by mechanical inoculation to local lesion $\mathrm{N}$-generesistant tobacco lines. TMV inoculum was obtained by grinding $5 \mathrm{~g}$ of homogenous dried infected tobacco leaf tissue in a mortar and pestle in buffer and diluting to $500 \mathrm{ml}$. Leaves to be inoculated were marked by removing the leaf tip. A small $5-\mathrm{cm}^{2}$ sponge soaked in TMV suspension was rubbed gently on the top of the leaf on the right side of the leaf mid-vein.

Plants used in these experiments were near-isogenic sibling shade tobacco inbred lines $\mathrm{O}-40$ or 8212 , or sibling inbred broadleaf tobacco breeding lines that were either homozygous susceptible or resistant to TMV at the $N$ locus.

Virus testing. Fresh tobacco leaf tissue was tested for TMV using a commercially available double-antibody sandwich alkaline phosphatase enzyme-linked immunosorbent assay (DAS-ELISA) kit for the common strain of TMV (Agdia Inc., Elkhart, IN). Healthy tobacco plants, plants infected with TMV, and buffer or virus controls were used in all experiments. All samples consisted of 3 by $4 \mathrm{~cm} \mathrm{(2.5} \mathrm{g)} \mathrm{of}$ green leaf tissue ground in a mortar and pestle in $2.5 \mathrm{ml}$ of Agdia general extraction buffer. Absorbance at $405 \mathrm{~nm}$ was measured with a 96-well plate reader (Titertek Multiskan Model 310C; Eflab Oy, Helsinki, Finland). A sample was considered positive if the average absorbance of replicate wells was two times that of the buffer control.

Field inoculations. In 1991, nearisogenic sibling lines of broadleaf wrapper tobacco resistant or susceptible to TMV were inoculated by rubbing a virus suspension on the topping wound after removing the primary inflorescence (topping) 40 or 46 days after transplanting, respectively. Twenty-four plants of each type were stalk cut to harvest the entire plant 16 days later and air cured for 8 weeks. Cured wrapper leaves were evaluated for green spot development. In 1993, 30 plants each of near-isogenic sibling lines of shade to- 
bacco cv. O-40 resistant or susceptible to TMV were inoculated as described above and leaves harvested and cured. In both years, leaves were classified as healthy (no green spots), green spot positive (with 1 to 24 green spots per leaf), or severe green spot (with more than 25 green spots per leaf). TMV-symptomatic leaves also were cured separately to allow a comparison of symptomatic versus asymptomatic leaves. Data were analyzed by the two-sample proportion test.

In 2004, transplants of TMV-resistant or -susceptible shade tobacco cv. 8212 were planted into a shade tent on two planting dates, either 8 June or 17 June 2004, in four rows (15 plants per row, $30 \mathrm{~cm}$ apart within rows with $39 \mathrm{~cm}$ between rows) of each type at each date. Leaves to be inoculated were marked by removing the leaf tip. A small $5-\mathrm{cm}^{2}$ sponge soaked in TMV suspension was rubbed gently on the top of the leaf on only one side of the leaf at midvein. Alternatively, the leaf petiole wound was inoculated by rubbing with the TMV suspension-soaked sponge shortly after picking the leaf. Plants within each of the four rows of each planting were either (i) leaf inoculated when axillary buds were removed by hand (suckering) on 9 July, (ii) leaf inoculated after the first prime (threeleaf harvest) on 6 August, (iii) inoculated at the petiole of the furthest leaf from the ground picked during the first prime on 6 August, or (iv) not inoculated. Shade tobacco plants ripen and are harvested from the bottom to the top as leaves age. Three plants per treatment per planting were sampled by removing the lowest leaf remaining and the highest fully expanded leaf on each plant. Leaves were

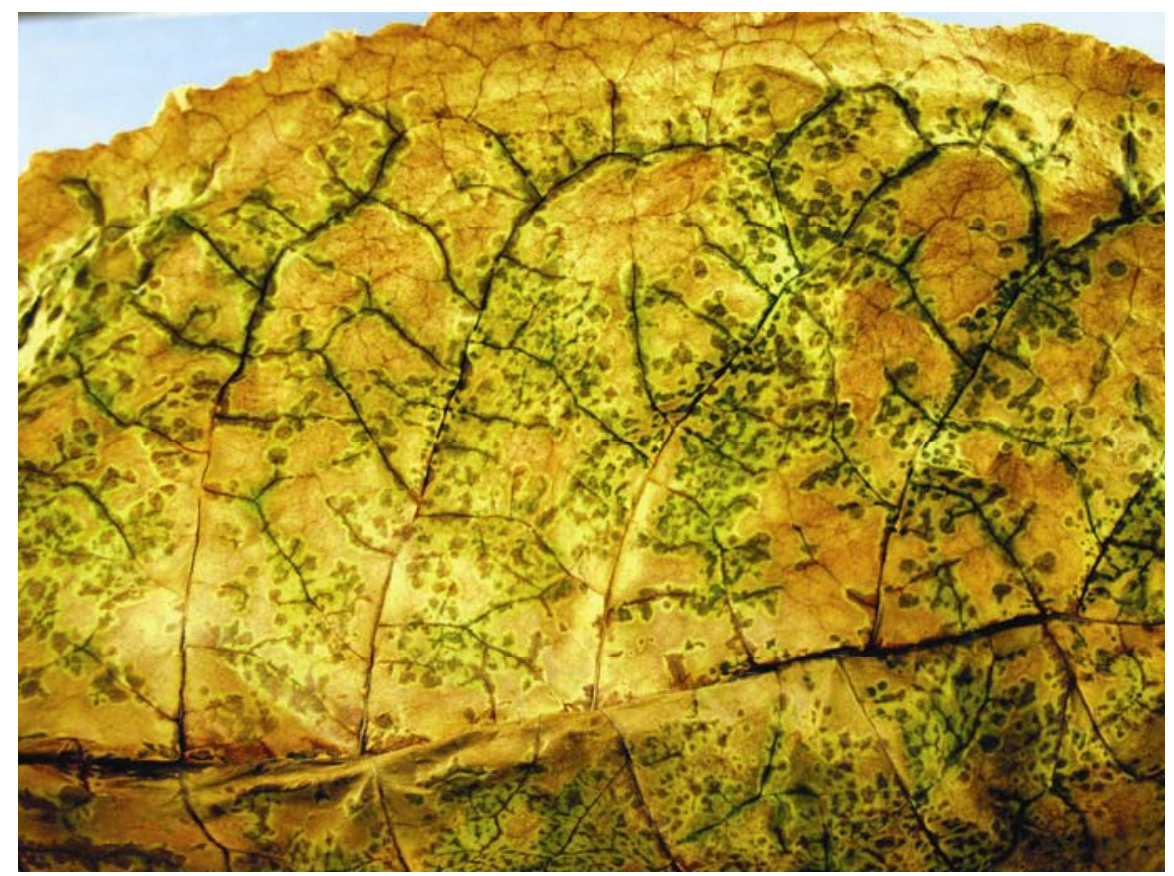

Fig. 1. Severe green spot symptoms on a cured shade tobacco cigar wrapper leaf. No disease was evident on the green leaf at picking. sampled on 27 July, 5 August, 8 September, and 27 October and green leaf tissue evaluated for TMV using ELISA as described above. In addition, three ripe leaves per plant were harvested and sewn to a lath to allow air curing on 24 August, 1 September, and 10 September. Harvested leaves were air cured for 8 weeks in a tobacco curing shed. Cured leaves were evaluated for green spot symptoms using a rating of 0 to 4 where $0=$ no green spots, $1=1$ to $10,2=11$ to 100,3 $=101$ to 1,000 , and $4=$ more than 1,000 green spots per leaf. Because leaf green spot ratings were not normally distributed, ratings from each of the 40 leaves evaluated were analyzed by the nonparametric Kruskal-Wallis test.

Growth chamber inoculation, 2005. Seedlings of near-isogenic lines of shade tobacco cv. 8212 were transplanted into a 1:1 mixture of pasteurized sandy loam field soil and Sunshine no. 3 potting mix (Fisons Western Corp., Downers Grove, IL) in $450-\mathrm{cm}^{3}$-capacity plastic pots. Eleven days after transplanting, plants were placed in growth chambers at either 23 or $31.5^{\circ} \mathrm{C}$ and held at constant temperature and $12 \mathrm{~h}$ of light per day. Plants were leaf inoculated with TMV as described above 4 days after being placed in each growth chamber. The experimental design was a factorial with two plant types (resistant or susceptible to TMV), two inoculation treatments (inoculated or not), two temperatures $\left(23\right.$ or $31.5^{\circ} \mathrm{C}$ ), and three replicates. The experiment was performed twice. Leaves were sampled 40 and 47 evaluated for TMV using DAS-ELISA as described above. days after inoculation and green leaf tissue
Field experiments, 2005. Transplants of TMV-resistant or -susceptible shade tobacco cv. 8212 were planted into a shade tent on 7 June 2005 in two single-row plots (30 plants per row). Plants were placed into soil $30 \mathrm{~cm}$ apart within rows with 39 $\mathrm{cm}$ between rows. Thirty plants each of TMV-resistant or -susceptible 8212 were inoculated with a TMV suspension as previously described on each of three dates: 20 July, 25 July, and 28 July. An additional 30 plants of each type were not inoculated. Maximum and minimum daily temperatures and duration of time above $28^{\circ} \mathrm{C}$ were measured at half-hour intervals in the shade tent at $2 \mathrm{~m}$ above the ground within the canopy using a CR23X micrologger (Campbell Scientific, Logan, UT). Measurements are presented in Table 1.

Three plants per plant type (TMVresistant or -susceptible) per inoculation date (three dates plus noninoculated) were sampled by removing the marked inoculated leaf and the highest fully expanded leaf on each plant. Leaves were sampled on 9 and 17 August and green leaf tissue evaluated for TMV using ELISA. In addition, three ripe leaves per plant were harvested and sewn to a lath on 23 August and 12 September. Harvested leaves were air cured for 8 weeks in a tobacco curing shed at the Experiment Station Farm (23 August) or in a commercial curing shed (Altadis, Inc., Enfield, CT, 12 September). Cured leaves were evaluated for green spot symptoms using a rating of 1 to 8 , where 1 = good quality, 2 = uneven but acceptable leaf color, $3=$ mild green tint to the leaf, 4 $=$ severe green tint to the leaf, $5=$ mild level of yellow-brown spots present, $6=$ severe level of yellow-brown spots present, $7=$ mild level of green spots present, and 8 $=$ severe level of green spots present. There were no differences in green spot ratings between the two curing locations; therefore, data were combined for analysis.

\section{RESULTS}

Field inoculations. The proportion of TMV-inoculated near-isogenic tobacco lines resistant or susceptible to TMV with

Table 1. Maximum (Max) and minimum (Min) daily temperatures and number of hours (Hours) above $28^{\circ} \mathrm{C}$ in a cloth-covered shade tent, Windsor, CT in 2005

\begin{tabular}{lccc}
\hline Date & Max & Min & Hours \\
\hline 20 July & 31.2 & 20.1 & 11.0 \\
21 July & 32.8 & 16.5 & 8.0 \\
22 July & 33.6 & 17.2 & 10.0 \\
23 July & 29.3 & 18.4 & 4.5 \\
24 July & 30.5 & 13.3 & 5.5 \\
25 July & 31.7 & 20.0 & 6.0 \\
26 July & 35.3 & 17.7 & 11.5 \\
27 July & 34.9 & 22.8 & 9.0 \\
28 July & 27.2 & 18.0 & 0.0 \\
29 July & 29.6 & 16.4 & 4.0 \\
30 July & 31.1 & 17.9 & 6.5 \\
31 July & 27.5 & 18.5 & 0.0 \\
1 August & 29.9 & 18.2 & 5.5 \\
\hline
\end{tabular}


green spot symptoms (one or more green spots per leaf) on cured leaves was greater for TMV-susceptible plants than for TMVresistant plants in both 1991 and $1993(P \leq$ 0.0001; Table 2). The differences between TMV-susceptible and -resistant plants were even greater when the proportions of cured leaves with severe green spot $(>25$ spots per leaf) were compared. Susceptible plants had many more (three to eight times) leaves with severe symptoms.

In 2004, TMV-inoculated resistant shade tobacco plants did not test positive for the virus at any time (Table 3 ). Noninoculated susceptible plants were also negative. However, leaf inoculation of susceptible plants resulted in more virus particles in the leaves than petiole inoculation, which only resulted in a weak positive on one of the two sample dates. More virus particles were found as a result of leaf inoculation than petiole inoculation. Also, early inoculation of leaves on 9 July resulted in greater virus titer than leaf inoculation at the first prime (three-leaf harvest). Nearly 1 month later, in fact, only TMVsusceptible plants inoculated on 9 July had visible symptoms of infection when leaves were harvested from 24 August through 10 September 2004.

Green spot development on cured leaves from TMV-inoculated plants in 2004 was influenced by resistance, time of harvest (prime), and inoculation technique (Table 4). TMV-resistant plants had much lower green spot ratings than susceptible plants $(P \leq 0.0001)$, averaging 0.7 versus 2.0 over the two plantings. This represents up to an order of magnitude difference in the number of green spots per leaf because a rating of $1=1$ to 10 and $2=11$ to 100 green spots per rated leaf. Green spot symptoms decreased by the third picking (fifth prime) for both resistant and susceptible plants in both plantings. Leaf inoculation on 9 July or at the first harvest resulted in similar green spot ratings.

Time of leaf harvest influenced green spot development. In the early planting, the first three-leaf harvest had the most severe green spot, and symptom severity decreased with time. In the older planting, green spot was highest in the second harvest and lowest in the third.

The interaction of inoculation technique with harvest period demonstrated that green spot symptom severity was highest in the first harvest for early inoculated plants (leaf inoculated at suckering on 9 July). Severity decreased with time. When inoculation was delayed to 16 August, leaves picked in the second harvest had more green spot than those picked before or after. Systemically inoculated plants (16 August) had more green spot in the first harvest. Symptoms decreased with time.

Growth chamber experiments, 2005. Temperature affected the increase of TMV particles in TMV-inoculated near-isogenic resistant or susceptible shade tobacco lines
(Table 5). At $23^{\circ} \mathrm{C}$, inoculated susceptible plants tested positive for TMV with ELISA; however, all noninoculated or inoculated resistant plants tested negative for the virus. At $31.5^{\circ} \mathrm{C}$, both resistant and susceptible tobacco plants inoculated with TMV tested positive. In the second experiment, a noninoculated plant tested positive for TMV (1 of 12 plants), likely due to mechanical transmission during watering.

Field experiment, 2005. Near-isogenic shade tobacco lines with resistance or susceptibility to TMV were leaf inoculated under hot or cooler conditions and the number of hours greater than $28^{\circ} \mathrm{C}$ after inoculation within the next 4 days was recorded (Table 1). The extent of TMV infection was determined by ELISA on two dates, 9 and 17 August 2005, for resistant and susceptible plants (Table 6). Despite the fact that as many as $35 \%$ of the half-hour intervals in the next 4 days after inoculation had temperatures higher than the threshold $\left(28^{\circ} \mathrm{C}\right)$ to break resistance, TMV-resistant plants under field conditions did not exhibit symptoms or test positive for TMV, even on the leaf that had been inoculated with the virus. TMVsusceptible plants developed typical TMV symptoms and were positive for virus particles, especially later in the season.

Cured leaves from these plots were evaluated for green spot severity (Table 7).
Resistant plants had reduced green spot severity compared with TMV-susceptible plants $(P \leq 0.0001)$. Temperature influenced the development of green spot on susceptible plants only. TMV-susceptible plants inoculated and exposed to higher temperatures for a longer period had more green spot than similar plants inoculated later or at cooler temperatures. A regression analysis of number of hours above $28^{\circ} \mathrm{C}$ within the $96 \mathrm{~h}$ after inoculation against green spot rating resulted in a significant linear relationship (model: green spot rating $=0.41 \times$ hours; $R^{2}=0.90$ ) TMV also was present late in the season in susceptible plants not intentionally inoculated, and green spot also was present in leaves from these plants, indicating that some inadvertent transmission of the virus had occurred, likely from activities of working in the block. TMV can be easily transmitted by mechanical means such as leaf contact or by workers touching plants.

\section{DISCUSSION}

Resistance to TMV, introduced into cultivated tobacco types from $N$. glutinosa (3), is single dominant gene resistance ( $N$ gene) derived from a chromosome substitution event. This resistance has been widely used in breeding programs; however, resistant cultivars have not been used consistently in all tobacco types, because $\mathrm{N}$-mediated resistance has been associated

Table 2. Proportion of Tobacco mosaic virus (TMV)-inoculated field-grown cured broadleaf (1991) or shade (1993) tobacco near-isogenic lines resistant or susceptible to TMV with green spot symptoms ${ }^{\mathrm{a}}$

\begin{tabular}{lcccccc}
\hline & \multicolumn{2}{c}{ Broadleaf, 1991 } & & \multicolumn{2}{c}{ Shade, 1993 } \\
\cline { 2 - 3 } \cline { 5 - 6 } TMV reaction & Green spot & Severe green spot & & Green spot & Severe green spot \\
\hline Susceptible & 0.89 & 0.61 & & 0.91 & 0.51 \\
Resistant & 0.48 & 0.08 & & 0.47 & 0.15 \\
$P \leq \mathrm{b}$ & 0.0001 & 0.0001 & & 0.0001 & 0.0001 \\
\hline
\end{tabular}

${ }^{\text {a }}$ Green spot $=$ at least one green spot per leaf and Severe green spot $=$ more than 25 green spots per leaf.

b Two-sample proportion test. Number of leaves sampled in $1991=116$ resistant and 138 susceptible. Number sampled in $1993=165$ resistant and 170 susceptible.

Table 3. Occurrence of Tobacco mosaic virus (TMV) in extracts of leaves of TMV-resistant or -susceptible tobacco inoculated at different times and harvested on 9 September and 27 October 2004 as determined by absorbance at $405 \mathrm{~nm}$

\begin{tabular}{llcc}
\hline & & \multicolumn{2}{c}{ Absorbance 405 nm } \\
\cline { 3 - 4 } Tobacco line & Inoculation and timing & 9 September & 27 October \\
\hline Conn shade 8212 nn & Leaf at suckering & $0.71^{*}$ & $0.53^{*}$ \\
Conn shade 8212 nn & Leaf at prime 1 & $0.15^{*}$ & $0.20^{*}$ \\
Conn shade 8212 nn & Petiole at prime 1 & $0.16^{*}$ & 0.13 \\
Conn shade 8212 nn & Noninoculated & 0.06 & 0.15 \\
Conn shade 8212 NN & Leaf at suckering & 0.04 & 0.12 \\
Conn shade 8212 NN & Leaf at prime 1 & 0.03 & 0.09 \\
Conn shade 8212 NN & Petiole at prime 1 & 0.06 & 0.12 \\
Conn shade 8212 NN & Noninoculated & 0.04 & 0.08 \\
ANOVA factor $(P \leq)^{\mathrm{b}}$ & & & 0.0001 \\
Tobacco line & $\ldots$ & 0.0001 & 0.0001 \\
Inoculation and timing & $\ldots$ & 0.0001 & 0.0001 \\
Interaction & $\ldots$ & 0.0001 &
\end{tabular}

${ }^{\text {a }}$ Buffer control $=0.04$ on 9 September and 0.08 on 27 October. Positive control $=0.70$ on 9 September and 0.31 on 27 October. Asterisk $(*)=$ positive enzyme-linked immunosorbent assay (average absorbance of replicate wells twice that of the buffer control).

b ANOVA (significance $P \leq$ ) = analysis of variance. 
Table 4. Severity of green spot symptoms on cured leaves of Tobacco mosaic virus-resistant or -susceptible tobacco inoculated at different times and harvested on three occasions, 2004

\begin{tabular}{|c|c|c|c|c|}
\hline \multirow[b]{2}{*}{ Tobacco line } & \multirow[b]{2}{*}{ Inoculation and timing } & \multicolumn{3}{|c|}{ Green spot rating $^{\mathrm{a}}$} \\
\hline & & Leaf prime $^{b}$ & Planting 1 & Planting 2 \\
\hline Conn shade $8212 \mathrm{nn}$ & Leaf at suckering & 3 & 2.9 & 2.4 \\
\hline Conn shade $8212 \mathrm{nn}$ & Leaf at prime 1 & 3 & 1.8 & 1.7 \\
\hline Conn shade $8212 \mathrm{nn}$ & Petiole at prime 1 & 3 & 2.4 & 2.4 \\
\hline Conn shade $8212 \mathrm{nn}$ & Noninoculated & 3 & 2.2 & 1.4 \\
\hline Conn shade 8212 nn & Leaf at suckering & 4 & 2.8 & 1.4 \\
\hline Conn shade $8212 \mathrm{nn}$ & Leaf at prime 1 & 4 & 2.6 & 2.1 \\
\hline Conn shade $8212 \mathrm{nn}$ & Petiole at prime 1 & 4 & 2.2 & 1.6 \\
\hline Conn shade $8212 \mathrm{nn}$ & Noninoculated & 4 & 1.7 & 2.4 \\
\hline Conn shade $8212 \mathrm{nn}$ & Leaf at suckering & 5 & 1.8 & 1.1 \\
\hline Conn shade $8212 \mathrm{nn}$ & Leaf at prime 1 & 5 & 2.5 & 2.0 \\
\hline Conn shade 8212 nn & Petiole at prime 1 & 5 & 1.8 & 0.8 \\
\hline Conn shade $8212 \mathrm{nn}$ & Noninoculated & 5 & 1.8 & 1.5 \\
\hline Conn shade $8212 \mathrm{NN}$ & Leaf at suckering & 3 & 1.1 & 0.9 \\
\hline Conn shade $8212 \mathrm{NN}$ & Leaf at prime 1 & 3 & 1.3 & 0.5 \\
\hline Conn shade $8212 \mathrm{NN}$ & Petiole at prime 1 & 3 & 1.0 & 0.7 \\
\hline Conn shade $8212 \mathrm{NN}$ & Noninoculated & 3 & 0.4 & 0.5 \\
\hline Conn shade $8212 \mathrm{NN}$ & Leaf at suckering & 4 & 1.6 & 0.6 \\
\hline Conn shade $8212 \mathrm{NN}$ & Leaf at prime 1 & 4 & 1.6 & 0.9 \\
\hline Conn shade $8212 \mathrm{NN}$ & Petiole at prime 1 & 4 & 0.5 & 0.4 \\
\hline Conn shade $8212 \mathrm{NN}$ & Noninoculated & 4 & 1.7 & 0.8 \\
\hline Conn shade $8212 \mathrm{NN}$ & Leaf at suckering & 5 & 0.5 & 0.1 \\
\hline Conn shade $8212 \mathrm{NN}$ & Leaf at prime 1 & 5 & 0.5 & 0.0 \\
\hline Conn shade $8212 \mathrm{NN}$ & Petiole at prime 1 & 5 & 0.4 & 0.2 \\
\hline Conn shade $8212 \mathrm{NN}$ & Noninoculated & 5 & 0.9 & 0.2 \\
\hline \multicolumn{5}{|l|}{ ANOVA factor $(P \leq)^{\mathrm{c}}$} \\
\hline Tobacco line & $\ldots$ & $\ldots$ & 0.0001 & 0.0001 \\
\hline Inoculation and timing & $\ldots$ & $\ldots$ & ns & 0.03 \\
\hline Leaf prime & $\ldots$ & $\ldots$ & 0.0001 & 0.0003 \\
\hline Inoculation $\times$ leaf prime & $\ldots$ & $\ldots$ & 0.001 & 0.05 \\
\hline
\end{tabular}

Table 5. Occurrence of Tobacco mosaic virus (TMV) in extracts of leaves of TMV-resistant or -susceptible tobacco inoculated or not and held at two temperatures in growth chambers (GC temp) as determined by absorbance at $405 \mathrm{~nm}$

\begin{tabular}{llccc}
\hline & & & \multicolumn{2}{c}{ Absorbance 405 nma } \\
\cline { 4 - 5 } GC temp $\left({ }^{\circ} \mathbf{C}\right)$ & Line & Inoculated & Experiment 1 & Experiment 2 \\
\hline 31.5 & Resistant & Yes & $0.27^{*}$ & $0.43^{*}$ \\
31.5 & Resistant & No & 0.13 & 0.12 \\
31.5 & Susceptible & Yes & $0.30^{*}$ & $0.42^{*}$ \\
31.5 & Susceptible & No & 0.11 & $0.21^{*}$ \\
23.0 & Resistant & Yes & 0.11 & 0.10 \\
23.0 & Resistant & No & 0.12 & 0.10 \\
23.0 & Susceptible & Yes & $0.30^{*}$ & $0.43^{*}$ \\
23.0 & Susceptible & No & 0.10 & 0.09 \\
\hline
\end{tabular}

${ }^{\text {a }}$ Buffer control $=0.10$ in experiment 1 and 0.09 in experiment 2 . Positive control $=0.26$ in experiment 1 and 0.38 in experiment 2 . Asterisk $(*)=$ positive enzyme-linked immunosorbent assay (average absorbance of replicate wells twice that of the buffer control).

with various levels of negative traits that may decrease yield and leaf quality (5). Tobacco resistance to TMV is genetically stable (3). Different tobacco types appear to carry different amounts and types of associated negative genes due to linkage drag effects. High-yielding, high-quality burley tobacco cultivars with $\mathrm{N}$-gene resistance have been widely grown, but resistant flue-cured cultivars have not been widely accepted (11). Shade and broadleaf cigar wrapper tobacco cultivars with resistance to TMV exhibit a slight yield depression but are of acceptable commercial quality. Care must be taken, however, to continually select for resistance in inbred within 10 to 15 years. Advanced nearisogenic sibling inbred lines resistant or susceptible to TMV identified by test crosses prior to releasing $\mathrm{C} 9$ were used in these experiments.

In 1990 and 1991, the loss of $N$-gene resistance from shade tobacco cv. O-40 was identified and associated with increased TMV development in the field and increased incidence of green spot on cured wrapper leaves. Our results from comparison of inoculated versus noninoculated TMV-susceptible O-40 demonstrated that green spot developed in TMV-inoculated nonsymptomatic leaves but not on leaves that had not been inoculated with the virus (data not shown). Near-isogenic TMVresistant or -susceptible lines inoculated with the virus had a very different response to TMV inoculation in the development of green spot symptoms on cured leaves. Growers in Connecticut and Massachusetts responded to the epidemic by switching to a newly developed shade wrapper cultivar resistant to TMV (cv. 8212). In 2003 and 2004, growers again observed increased symptoms of green spot on cured leaves, and subsequent testing in our laboratory determined that the majority of tobacco identified as 8212 being grown was no longer resistant to TMV.

In the 1999 and 2000 growing seasons, a widespread epidemic of TMV occurred in flue-cured tobacco $(9,11)$. The use of TMV-infected tobacco products such as cigarettes by workers handling the crop may have served as a source of virus inoculum. TMV-susceptible plants inoculated early resulted in typical mosaic symptoms in our experiments (6). Plants inoculated later in the season after most leaves had expanded exhibited symptoms only on suckers. Resistant plants did not develop mosaic symptoms in the field.

To rule out the possibility that the epidemic was due to a TMV strain capable of infecting $\mathrm{N}$-gene plants (8), we collected virus from multiple fields and inoculated known $N$-gene-resistant plants. These plants responded with a typical hypersensitive response and did not allow replication of the virus. Additionally, TMV resistance has been shown to be dependent on temperature. In has been reported that temperatures greater than $28^{\circ} \mathrm{C}$ result in an inactivation of the resistance response (1). Our experiments demonstrated that this phenomenon occurred with the $N$ gene in the shade tobacco genome under controlled environmental conditions. However, because field conditions in cloth-covered shade tents decrease light intensity and increase temperature and humidity over ambient conditions (10), we were concerned about these effects on resistant plant response. We inoculated plants under different temperatures in the shade tent to test these conditions. TMV increases within inoculated leaves for 3 to 4 days prior to systemic movement (6); therefore, we recorded the 
Table 6. Effect of number of hours above $28^{\circ} \mathrm{C}$ after inoculation on the occurrence of Tobacco mosaic virus (TMV) in extracts of leaves of TMV-resistant or -susceptible tobacco in a 2005 field experiment as determined by absorbance at $405 \mathrm{~nm}$

\begin{tabular}{|c|c|c|c|c|c|}
\hline \multirow[b]{2}{*}{ Plot } & \multirow[b]{2}{*}{$\mathrm{H}>28^{\circ} \mathrm{CAI}$} & \multirow[b]{2}{*}{ Line } & \multirow[b]{2}{*}{ Leaf sampled ${ }^{b}$} & \multicolumn{2}{|c|}{ Absorbance 405 nma $^{a}$} \\
\hline & & & & 9 August & 17 August \\
\hline 1 & 33.5 & Resistant & Upper expanded & 0.08 & 0.07 \\
\hline 1 & 33.5 & Resistant & Inoculated far side & 0.07 & 0.07 \\
\hline 1 & 33.5 & Resistant & Inoculated side & $\ldots$ & 0.07 \\
\hline 1 & 33.5 & Susceptible & Upper expanded & $0.27 *$ & $0.40 *$ \\
\hline 1 & 33.5 & Susceptible & Inoculated far side & $0.28 *$ & $0.39 *$ \\
\hline 1 & 33.5 & Susceptible & Inoculated side & $\ldots$ & $0.34 *$ \\
\hline 2 & 26.5 & Resistant & Upper expanded & 0.07 & 0.09 \\
\hline 2 & 26.5 & Resistant & Inoculated far side & 0.09 & 0.12 \\
\hline 2 & 26.5 & Resistant & Inoculated side & $\ldots$ & 0.11 \\
\hline 2 & 26.5 & Susceptible & Upper expanded & 0.21 & $0.39 *$ \\
\hline 2 & 26.5 & Susceptible & Inoculated far side & $0.24 *$ & $0.24 *$ \\
\hline 2 & 26.5 & Susceptible & Inoculated side & $\ldots$ & $0.32 *$ \\
\hline 3 & 10.5 & Resistant & Upper expanded & 0.10 & 0.11 \\
\hline 3 & 10.5 & Resistant & Inoculated far side & 0.14 & 0.07 \\
\hline 3 & 10.5 & Resistant & Inoculated side & $\ldots$ & 0.08 \\
\hline 3 & 10.5 & Susceptible & Upper expanded & 0.14 & $0.41 *$ \\
\hline 3 & 10.5 & Susceptible & Inoculated far side & 0.10 & $0.19 *$ \\
\hline 3 & 10.5 & Susceptible & Inoculated side & $\ldots$ & $0.24 *$ \\
\hline
\end{tabular}

${ }^{\text {a }}$ Buffer control $=0.12$ on 9 August and 0.09 on 17 August. Positive control $=0.27$ on 9 August and 0.38 on 17 August. Asterisk $(*)=$ positive enzyme-linked immunosorbent assay (average absorbance of replicate wells twice that of the buffer control).

b Three arbitrarily chosen plants were sampled by removing the marked inoculated leaf (and testing either the inoculated side of the leaf or the far side on the other side of the midvein) and the highest fully expanded leaf on each plant. Leaves were sampled on 9 and 17 August.

number of hours above $28^{\circ} \mathrm{C}$ within a 4-day period after inoculation.

Our results demonstrated that TMV resistance was not broken by fluctuating temperatures with as many as 33.5 of $96 \mathrm{~h}$ above $28^{\circ} \mathrm{C}$ immediately after inoculation. TMV was not detected by ELISA on resistant plants on inoculated leaves or on upper leaves of the plant.

Although $\mathrm{N}$-gene-mediated resistance was the most important factor in reducing TMV titer and green spot development, resistant plants were not free of all green spot symptoms. Green spots on the leaves have been reported to contain little or no TMV compared with the light green areas of infected leaves and, in fact, virus-free plants have been regenerated from green islands on TMV-infected leaves (7). It is possible that the green spot symptom may be the result of a local or systemic plant resistance response to TMV infection. TMV-resistant plants accumulated $N$ mRNA in upper, noninoculated leaves, which lasted at least 10 days after inoculation (4). This movement of the signal for $N$-mRNA from the inoculated to the upper leaves did not result in a hypersensitive response; however, plants were still resistant to several viruses, demonstrating that resistance was uncoupled and separate from the hypersensitive response.

Green spot peaks at some point after inoculation and then declines. This has been reported by growers and is evident in our data where we observed an inoculationprime interaction. When plants were inoculated early, green spot was most severe in the first harvested leaves and declined in the second and third three-leaf harvests. When leaves were inoculated late, the greatest amount of green spot occurred in the second cohort of harvested leaves.

Virus resistance is a two-stage process, the first involving rapid cell death and collapse and the second involving an extended period where low titer cells are eliminated (12). Yu et al. (13) concluded that cell death and resistance were separate processes. An Arabidopsis mutant with constitutively high levels of salicylic acid did not exhibit a hypersensitive response, but was still resistant when challenged with TMV. Zhang et al. (14) determined that salicylic acid mediates systemic acquired resistance but not the hypersensitive response in tobacco. Systemic resistance to TMV develops in resistant tobacco plants after local lesion development (2). Therefore, we hypothesize that the development of green spot symptoms on cured leaves may be the result of either systemic infection of TMV-susceptible plants or associated with the systemic acquired resistance response to TMV infection of resistant plants.

\section{ACKNOWLEDGMENTS}

I thank J. Canepa-Morrison, S. Lamoureux, and R. Horvath for technical assistance; and Altadis, Inc. for curing shade tobacco leaf samples.

\section{LITERATURE CITED}

1. Canto, T., and Palukaitis, P. 2002. Novel $N$ gene-associated, temperature-independent resistance to the movement of Tobacco mosaic virus vectors neutralized by a Cucumber mosaic virus RNA1 transgene. J. Virol. 76(24):12908-12916

2. Hecht, E. I., and Bateman, D. F. 1964. Nonspecific acquired resistance to pathogens resulting from localized infections by Thielaviopsis basicola or viruses in tobacco leaves. Phytopathology 54:523-530.

3. Holmes, F. O. 1938. Inheritance of resistance to tobacco-mosaic disease in tobacco. Phyto-
Table 7. Effect of number of hours above $28^{\circ} \mathrm{C}$ after inoculation on the occurrence of green spot symptoms on cured leaves of Tobacco mosaic virus-resistant or -susceptible tobacco, 2005 field experiment

\begin{tabular}{lll}
\hline $\mathbf{H}>\mathbf{2 8}^{\circ} \mathbf{C A I}^{\mathbf{a}}$ & $\begin{array}{c}\text { Tobacco } \\
\text { line }\end{array}$ & $\begin{array}{c}\text { Green spot } \\
\text { rating }^{\mathbf{b}}\end{array}$ \\
\hline 33.5 & Resistant & 2.6 \\
33.5 & Susceptible & 6.4 \\
26.5 & Resistant & 3.1 \\
26.5 & Susceptible & 5.3 \\
10.5 & Resistant & 2.6 \\
10.5 & Susceptible & 4.2 \\
0 & Resistant & 2.6 \\
0 & Susceptible & 4.0 \\
ANOVA & & \\
T & $\ldots$ & 0.00001 \\
L & $\ldots$ & 0.00001 \\
T $\times$ L & $\ldots$ & 0.00002 \\
\hline
\end{tabular}

a Number of hours of $96 ; 0=$ noninoculated; ANOVA factor (significance $P \leq$ ) $=$ analysis of variance for temperature $(\mathrm{T})$, line resistance $(\mathrm{L})$, and temperature-line interaction $(\mathrm{T} \times \mathrm{L})$.

${ }^{\mathrm{b}}$ Green spot rating of 1 to 8 , where $1=\operatorname{good}$ quality, 2 = uneven but acceptable leaf color, $3=$ mild green tint to the leaf, $4=$ severe green tint to the leaf, $5=$ mild level of yellow-brown spots present, $6=$ severe level of yellow-brown spots present, $7=$ mild level of green spots present, and $8=$ severe level of green spots present.

pathology 28:553-561.

4. Levy, M., Edelbaum, O., and Sela, I. 2004 Tobacco mosaic virus regulates the expression of its own resistance gene $N$. Plant Physiol. 135:2392-2397.

5. Lewis, R. S., Milla, S. R., and Levin, J. S. 2005. Molecular and genetic characterization of Nicotiana glutinosa L. chromosome segments in Tobacco mosaic virus-resistant tobacco accessions. Crop Sci. 45:2355-2362.

6. Lucas, G. B. 1975. Diseases of Tobacco. Third Edition. H. E. Parker and Sons, FuquayVarina, NC

7. Murakishi, H. H., and Carlson, P. S. 1976 Regeneration of virus-free plants from darkgreen islands of tobacco mosaic virus-infected tobacco leaves. Phytopathology 66:931-932.

8. Padgett, H. S., and Beachy, R. 1993. Analysis of a Tobacco mosaic virus strain capable of overcoming $N$ gene-mediated resistance. Plant Cell 5:577-586.

9. Pappu, H. R., and Bertrand, P. F. 2000. Outbreak of Potato Y potyvirus and Tobacco mosaic tobamovirus in Georgia's flue-cured tobacco. Plant Dis. 84:201.

10. Waggoner, P. E., Pack, A. B., and Reifsnyder, W. E. 1959. The climate of shade. Conn. Agric. Exp. Stn. Bull. 626.

11. Wilkinson, C. A., Reed, T. D., Johnson, C. S., and Jones, J. L. 2001. Flue-cured tobacco variety information for 2001. Va. Coop. Ext. Publ 436-047.

12. Wright, K. M., Duncan, G. H., Pradel, K. S. Carr, F., Wood, S., Oparka, K. J., and Cruz, S. S. 2000. Analysis of the $N$ gene hypersensitive response induced by a fluorescently tagged tobacco mosaic virus. Plant Physiol. 123:13751385 .

13. Yu, I. C., Parker, J., and Bent, A. F. 1998. Genefor-gene disease resistance without the hypersensitive response in Arabidopsis dnd1 mutant. Proc. Natl. Acad. Sci. USA 95:7819-7824.

14. Zhang, Z.-G., Wang, Y.-C., Li, J., Ji, R., Shen, G., Wang, S.-C., Zhou, X., and Zheng, X.-B. 2004. The role of SA in the hypersensitive response and systemic acquired resistance induced by elicitor PB90 from Phytophthora boehmeriae. Physiol. Mol. Plant Pathol. 65:31-38. 